\title{
Bibliocircuitry and the Design of the Alien Everyday
}

\author{
Charity Hancock, Clifford Hichar, Carlea Holl-Jensen, \\ Kari Kraus, Cameron Mozafari, and Katbryn Skutlin
}

\begin{abstract}
This essay describes, models, and advocates for the role of reflective design in bibliography and textual studies. Popularized by Donald Norman, reflective design promotes critical inquiry over usability and exploratory prototyping over fully realized productions. We highlight four projects undertaken by the authors that embody reflective design, including three that explore the crossed codes of print and electronic books. A larger aim of the essay is to position bibliotextual scholarship and pedagogy as design-oriented practices that can be used to imagine the future as well as reconstruct the past.
\end{abstract}

\section{I} Michael Smith-Welch, a leading figure in the Maker movement, shows an image of a vintage General Electric print advertisement from the early 20th century (Sмith-WeLCh 2013). At the center of the ad are two refrigerators, one closed, the other open and well-stocked with food (Figure 1). Emblazoned above them are the words "The Finest Refrigerators General Electric Ever Built". On either side is a captive audience of men and women dressed in formal evening wear gazing admiringly at them, unable to turn away.

By way of unpacking this curious scene, Smith-Welch reminds us that once upon a time refrigerators were novel technologies, things to be marveled and exclaimed over rather than taken for granted. Today, he suggests, we do the same thing with our fancy 3D printers, shiny gadgets, and robotic vacuums: we marvel. "But that will go away," Smith-Welch opines. "They will become part of our everyday life. And that's great, but my point" — and here we come to his central thesis - "is to make sure they don't quite disappear" (2013).

Currently an artist-in-residence with the American Visionary Art Museum and part of the instructional team behind FutureMakers, a mobile makerspace, Smith-Welch has spent much of his career developing new 


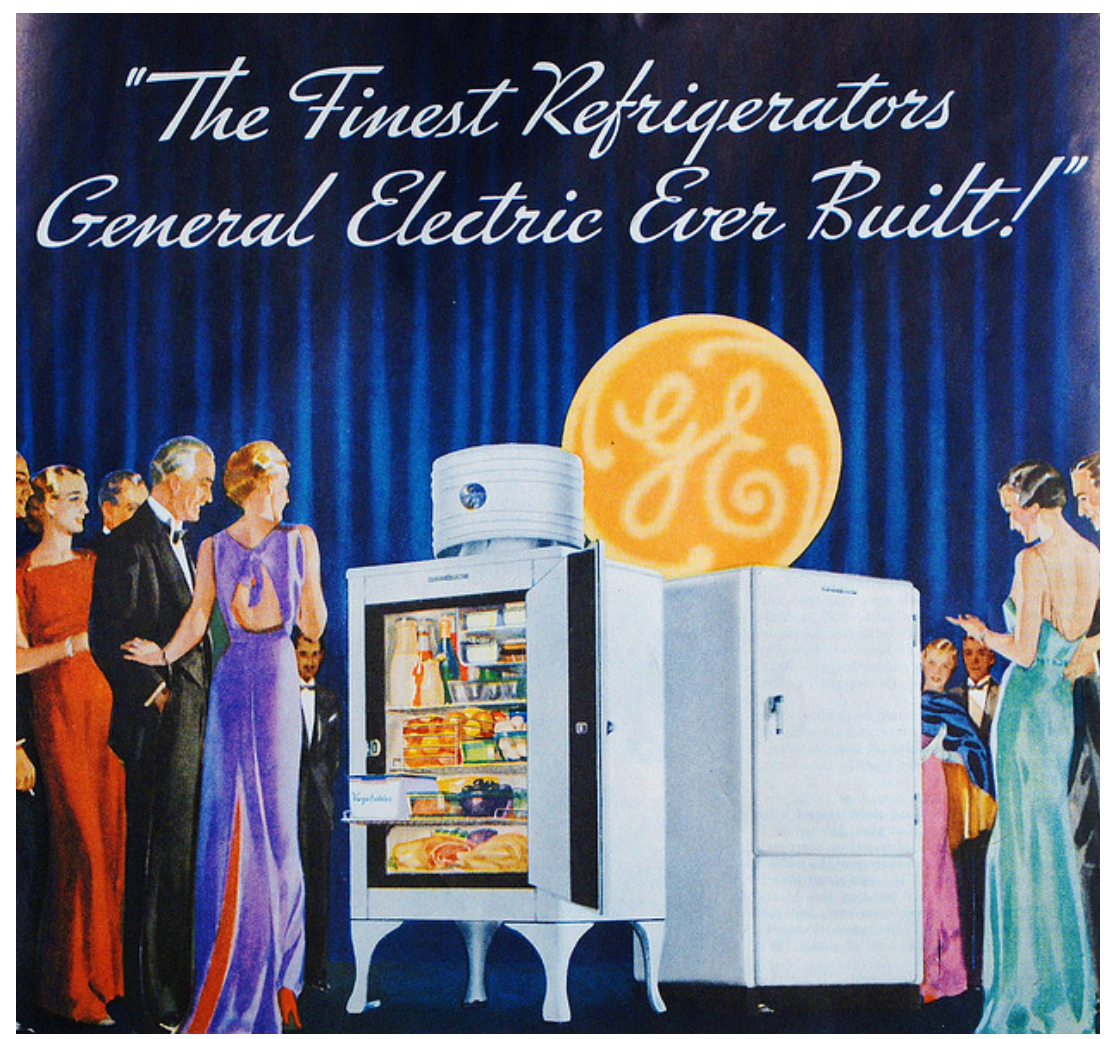

Figure 1. Vintage General Electric print advertisement for the "Monitor-Top" refrigerator (1934). Source: http://www.dieselpunks.org/profiles/blogs/refrigerator-age.

learning technologies for kids and advocating for tinkering as a way of knowing. "Don't let the computer disappear!" has become his mantra for expressing the conviction that new computational tools and platforms should be inspectable, modifiable, and programmable if they are to fulfill their educational promise. For that reason, their technical wizardry must remain visible, because the moment it disappears, the devices become impenetrable black boxes, closed to investigative reasoning.

Smith-Welch's distinction between visible and invisible technology can be usefully mapped onto the influential human-technology relationships defined by philosopher Don Ihde. In Ihde's terminology, a transparent instrument or technology — one that recedes from view — gives rise to either an embodiment relation, in which the technology becomes an extension of the self (a hammer, a pair of eyeglasses) or a hermeneutic relation, in which the technology becomes a vehicle for displaying a conventionalized 
notation or writing system (a thermometer, a literary text) that references the world (1990, 72-96). Embodiment relations allow us to see through a technology, while hermeneutic relations allow us to see with a technology (Pierce and Paulos 2011, 2406). Conversely, an intrusive technology - one in which the medium continually distracts us from the message, or the object relentlessly asserts its status as object - gives rise to an alterity relation. While alterity relations may sometimes be the consequence of technical malfunctioning or breakdown (e.g., the notorious "blue screen of death" displayed by the Windows operating system), they are just as often the product of fascination and curiosity, and thus frequently carry positive associations (Ihde's example is the whimsy of a spinning top [1990, 100]). Alterity relations allow us to look at a technology, rather than through it or with it (Pierce And Paulos 2011, 2406). Smith-Welch's argument, then, recast from this vantage point, is that alterity relations have a critical role to play in achieving technological fluency, and embodiment or hermeneutic relations may in some instances interfere with that.

In this essay we apply Smith-Welch's insights to the book as material artifact. In everyday contexts, printed books - like household appliances, old wallpaper, or the floorboards beneath our feet - "withdraw" from view, to invoke Ihde's terminology $(1990,48)$. They do so principally by virtue of their familiarity: it is their very ordinariness that makes them invisible. The field of bibliotextual studies has partially overcome this limitation through recourse to history: when we take the long view, the instability of the book and the myriad forms it has assumed - clay tablet, papyrus scroll, codex manuscript, and e-device, to name a few - serve to radically defamiliarize it. History thus provides an extensive reservoir of diverse bibliographic models whose ongoing availability, when taken advantage of, can help restore alterity relations.

Method plays a crucial role too. Physical bibliography, perhaps more than any other literary subdomain, is a hands-on discipline involving specialized instruments (collators, magnifying glasses, raking light); instructional materials (facsimile chain line paper and format sheets); and analytic techniques (examination and description of format, collation, typography, paper, binding, and illustrations). Book history courses frequently include not only lab exercises, but also studio exposure to bookbinding, printing, and papermaking. To study the book as a material object, then, is to make use of the hands. Such "tinker-centric pedagogy," as Jentery Sayers calls it $(2011,279)$, deepens the alterity relation by enabling us to engage more fully with the thingness of books - with their tactility as much as their visual properties. The tactile experience draws on an expanded range of gestures and manual operations to reveal the secrets of the book's material 
composition: holding it up to the light, turning it upside down, pressing a magnifying glass to its surface, even physically dissecting it if the book in question is part of a teaching collection. Nor is apprehension limited to just sight and touch: the quest for book knowledge enlists all our senses. Nostalgic discourse surrounding the printed book often invokes smell, for example, and bibliographic lore is replete with mentions of the bibliophagi, or book-eaters, chewing and ingesting pulp. ${ }^{1}$

In this essay we introduce the practice of reflective design as a means of establishing alterity relations and working toward technological fluency in the domain of bibliography and textual studies. Reflective design complements the recent emphasis on critical making in the digital humanities: the embodying of ideas or arguments in things. Ian Bogost's carpentry, Wolfgang Ernst's media archaeology, and Bruce Sterling's design fiction are all significant disciplinary touchstones. Part of the human-centered design philosophy of Donald Norman, reflective design foregrounds critical investigation over usability. In his classic book on emotional design, Norman situates reflective design within a tripartite system exemplified by three teapots that sit atop his kitchen shelf:

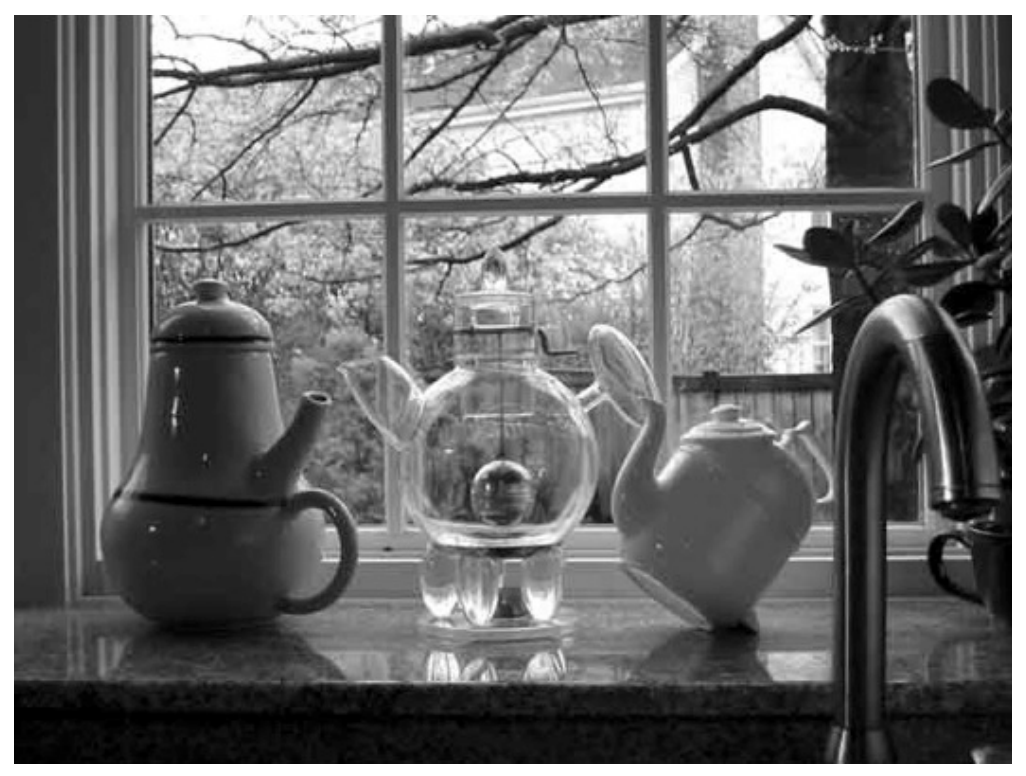

Figure 2. Norman's teapots, each emphasizing a different design paradigm. From left to right: reflective, visceral, and behavioral design (From Norm an 2004, 5).

1. On the bibliophagi, see JACKsON 1950, 154-73. 
Norman's so-called "masochistic" teapot on the left is rendered perversely unusable by the position of the spout above the handle; the Nanna teapot in the middle combines charm and functionality; and the tilting teapot on the right - which involves temporarily leaning the pot backward to steep the tea leaves - is an exercise in studied usability. Adopting the terminology of reflective, visceral, and behavioral to refer to the predominant design orientation of each, Norman argues that "it is not possible to have a story about design without all three". However disparate the teapots seem, taken together they speak to a coherent design philosophy; they combine an applied perspective (the behavioral dimension) with a more playful or provocative one (the reflective dimension) (Norman 2004, 5-6). The visceral dimension exemplified by the Nanna teapot brings beauty into the equation as well. ${ }^{2}$

The role of reflective design in this trio is key: it is what helps us discover fault lines in the objects, artifacts, or systems being explored — the location of a teapot's spout or, say, the stitched binding that turns otherwise loose sheets of paper into books - and in doing so allows us to imagine them otherwise: to see them as alterable rather than immutable; as possibility spaces rather than rigid, inherited structures. ${ }^{3}$ It is this dimension of design that allows us to envision ourselves as creative agents of change.

The subjunctive perspective enabled by reflective design - the ability to inhabit the possibility space of the "what-if?" — is an essential component of technological fluency. Defined by Jonathan Lukens and Carl DiSalvo as "the capability to understand, use, and assess technology beyond its rote application" $(2012,24)$, technological fluency is sharply distinguished from literacy:

Fluency, in contrast to literacy, affords creativity. If I am literate in a language, I can read, write, and speak it, but if I am fluent in a language I can write poetry or a novel or use the language in ways the literate cannot. Technological fluency is the ability to be creative with technology; it is a vital component in a participatory culture in which the design, use, and evaluation of technologies is an open process that goes beyond the purview of experts. (24)

2. This paragraph and the one that follows originally appeared in modified form in Kraus 2012.

3. This cognitive view of creativity is elaborated in Byrne 2007, 194-6. Byrne adopts the language of "faultlines" and "joints" in reality to characterize the counterfactual process, which she in turn borrows from Douglas Hoftstadter. 
Drawing on the National Research Council report "Being Fluent with Information Technology" (1999), Lukens and DiSalvo point to the importance of adopting a future-oriented perspective and "anticipating and adapting to changing technologies" $(2012,27)$. Within the context of bibliotextual studies, reflective design not only disarms complacency, allowing us to see the book-as-artifact anew, but also foreshadows alternative conceptions of the book. Common labels that have emerged for such prefigurative models or representations include "design fiction" (Bosch 2012), "speculative design" (Lukens and DiSalvo 2012) and "imaginary media" (PARIKK A 2012, 41-62). In our usage, reflective design may be viewed independently of these practices, or as a natural adjunct to them. As previously stated, one of its primary purposes is to defamiliarize an object by making its constituent parts, attributes, properties, or affordances visible and explorable, thereby revealing potential sites of change. Reflective design can also act as a staging area for design fiction, a space where essential preparatory and experimental work can be carried out.

In the sections that follow, we introduce four prototype projects undertaken by the co-authors as part of Kraus's fall 2012 seminar, "Book 2.0: The History of the Book and the Future of Reading". Each project shows reflective design at work, reminding us that prevailing notions of "bookness" aren't hard-coded into reality, but are instead susceptible to change. Each also extends the tradition of critical making that has long characterized History of the Book studies, as well as some strands of textual scholarship, such as the deformative practices of Jerome McGann and Lisa Samuels. And finally, three of the projects can be interpreted to varying degrees as artifactual rejoinders to so-called digital dualism: the fallacy that analog and digital are entirely distinct and separate domains (JURGENSON 2011). Both Hichar and Mozafari's books, for example, are intricate cross-wirings of atoms and bits. While physical books serve as the base or substrate of their designs, their functionality is enhanced by the addition of miniature computers known as microcontrollers, which transform the books into programmable media. Adopting a different set of strategies, Hancock and Skutlin's print book includes sections that visually imitate the user interface of Twitter, the popular microblogging service, thus blending the semiotic codes of page and screen. Such impersonation occurs frequently in transmedia storytelling, where media - like characters — often serve as doppelgangers of one another. ${ }^{4}$ Although such a print rendition of Twitter

4. Alternate Reality Games (ARGs) and other transmedia fictions are often structured by one medium "composting" another, to borrow a metaphor from Bruce 
lacks interactivity, it required the authors to compose text in units of 140 characters or less each, a constraint that proved to be highly generative.

As used in our title, the term "bibliocircuitry" is meant to capture the spirit of reflective design. In one sense, we are interested in thinking about physical books as platforms for experimenting with computation. But we also intend the term figuratively and more broadly to refer to a range of exploratory methods, such as those adopted by Carlea Holl-Jensen, that can lead - vitally — to understanding the codex form in new and different ways. Like anatomical illustrations that reveal inner tissues and organs, these methods permit us to see the unseen: the circuitry of books that combine pulp and silicon, but also the everyday material and structural affordances of books, which are so engrained in the culture that they habitually go unnoticed.

By making the page, not the screen, the experiential site of computation, Hichar and Mozafari explore what Steven Johnson calls the "adjacent possible": alternative cultural configurations that grow out of the present order of things (2010, 23-42). Hichar's The Pussycat Said to the Owl is an altered book in the tradition of British artist Tom Phillips' A Humument, which surfaces a new narrative out of a pre-existing Victorian novel by selectively collaging and painting over the text, leaving some fragments intact to tell a radically different story. In Hichar's case, an unlikely base text serves as the occasion for a visual adaptation of Edward Lear's classic nineteenthcentury nonsense poem, "The Owl and the Pussycat". Neither born-digital nor digitized — nor yet entirely paper-based - Hichar's electronic book is a hybrid space in which analog and digital components are co-expressive. Exemplifying an emergent form of e-literature, The Pussycat Said to the Owl uses its bibliocircuitry to animate otherwise static print pages of text and illustration. Consistent with Andrew Piper's claim that "the digital provides us with a critical lens to see the bibliographic with fresh eyes" (2009, 8), Hichar has invested her found book with new affordances while simultaneously preserving the old. As her account makes clear, reflective design infuses process as much as product: the act of integrating several Arduinos into the project attuned her to the materiality of the page and the body plan of the book in ways that would have been quite impossible otherwise.

Sterling $(2005,14)$ : i.e., the signs of one communication channel are translated into those of another. In the Cathy's Book ARG franchise, for example, an email or SMS GUI is frequently visually rendered on the page, capturing the look - if not the materiality or interactivity — of the original digital environment (Stewart et al 2008). 
The thickness and opacity of the paper and the volumetric space of the artifact dictated design constraints and opportunities. The result is a harbinger of future bookscapes in which the mixing of material and digital fabrication is commonplace. ${ }^{5}$

Unlike a sleek contemporary machine whose protective outer covering serves to conceal what lies within, the first draft of a new technology often exposes its own mechanisms, making it seem less a mass-produced commodity than a bespoke design. While it may indeed be the case, as Arthur C. Clarke would have it, that any "sufficiently advanced technology is indistinguishable from magic," this claim does not usually extend to a technology's embryonic states, which can seem almost to carry the blueprints of their own design. The wireframe fuselage of the Wright brothers' 1903 aircraft clearly reveals how the plane was constructed, for example, and steam-powered precursors of the automobile often look like they're held together by duct tape and chewing gum. Similarly, the open design of Mozafari's interactive book, like a cutaway diagram of a train, shows precisely how the book was made. With the help of a microcontroller board and alligator clips, Mozafari embeds his print edition of Coleridge's "Kubla Khan" with touch-triggered sound, giving the reader a multisensory experience of the poem. Like the "guts on the outside" futurist techniques of the Archigram collective - who in the 1960s celebrated buildings with exposed pipes and tubes-Mozafari's book flaunts its status as technology by not attempting to hide its electrical components (Medway 2008). In addition to scaffolding learning and creativity, the project is consistent with a long tradition of speculative design making use of such externalization of parts. ${ }^{6}$

5. Improbably, the same type of miniature device controlling the LEDs embedded in Hichar's luminous illustrations is also used to help power the Large Hedron Collider at the CERN laboratory in Switzerland. From a personal odyssey to reimagine what a book might be to the collective quest to understand the physics of the universe, the versatile Arduino platform underlies both. See BANZI 2012.

6. One example - greebling — originates in the movie industry (WIK IPEDI A 2013). Also described as "guts on the outside," greebling refers to the practice of covering the surface of spaceship models designed for science fiction cinema with a finely milled mash-up of parts from hobbyist model kits (WiKipEdia 2013). This technique was thought to give the spacecraft a more futuristic appearance. Similarly, steampunk design is notable for the extrusion of mechanical parts such as wheels, gears, cogs, and springs onto the surfaces of objects, such as clocks. 
In the sections that follow, each author adopts the first person "I" perspective to highlight salient themes and ideas expressed in their productions, as well as details related to process and materiality. We conclude the essay with some final thoughts on the role of design - both reflective and speculative - in physical bibliography and textual criticism.

\section{“The Hollow": Form That Foils Content (Carlea Holl-Jensen)}

My project arose from a curiosity about how the form of a book might prevent, or at least frustrate, access to the text, in order to manipulate the reader's experience of its content and challenge her understanding of the text's meaning.

To answer this question, I devised a format for a single-signature book in which a single sheet of paper is folded so that four of the exterior edges of the finished book are uncut bolts. In physical bibliography, "bolts" are the folded edges that result from folding larger sheets of paper into a gathering or quire (Belanger and Herdrich 2007, 16). In familiar bindings such as quarto and octavo, one or two edges may be folded - and would traditionally have been cut open, either by the printer or by the owner of the book - but never all three edges. The diagram below demonstrates the process of folding the book (Figure 3).

As a result of this design, only four of thirty-two pages are immediately available to the reader. All other pages are inaccessible within the folded paper, with the exception of some of the interior pages on the verso side of the open book, which can be glimpsed but not fully unfolded (Figure 4).

The quire may be cut open, but only at the risk of destroying the integrity of the book itself, as some of the pages may come loose when the edges are cut, and parts of the text may even be destroyed.

Such a format explores the opportunities presented by what Matthew Kirschenbaum calls the comparative space of the book: "the two-page opening of a standard codex, presenting recto and verso pages to the reader" $(2008,2)$. The pages that face one another, which seem to present a continuous narrative, in fact obscure a significant portion of the narrative within. Instead of a genuine affordance (visual information that reliably indicates how an object should be used or operated), they telegraph a false affordance (a deceptive cue that signals a type of use that the object ultimately cannot deliver on) (GAVER 1991). The text appears to be readable as a coherent narrative, but this appearance is misleading. Though the exterior narrative 
1. Begin with a rectangular sheet of paper.

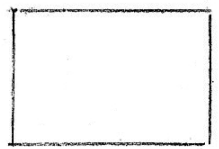

4. Fold right side to center, so that right crease rests in center fold.

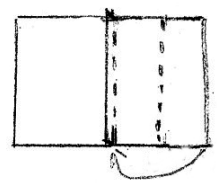

7.
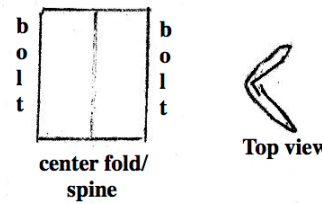

Top view

10. Repeat step 3, folding to center.

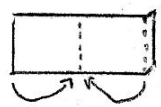

13. Repeat step 6, fold left leaf to center, adhere to tab.

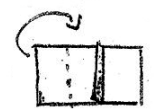

16. Punch 3 holes

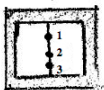

2. Fold back a small tab on the right side of the paper.

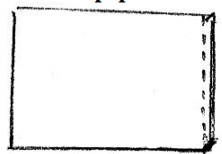

5. Apply adhesive to tab (optional).

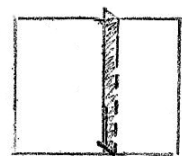

8. Turn booklet so the center fold is at the bottom.

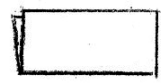

spine

11. Repeat step 4, fold right side to center.

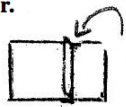

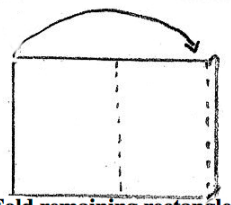

3. Fold remaining rectangle at center (left edge to right crease)

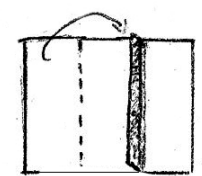

6. Fold left leaf to center, laying the edge over tab.

9. Repeat step 2, folding back a small tab on the right side of the booklet.

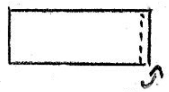

12. Apply adhesive.

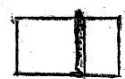

15. Place inside cover.

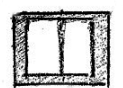

18. Tie off thread.

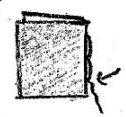

Figure 3. Folding format created by Holl-Jensen to maximize the number of bolted or uncut edges of the book. 


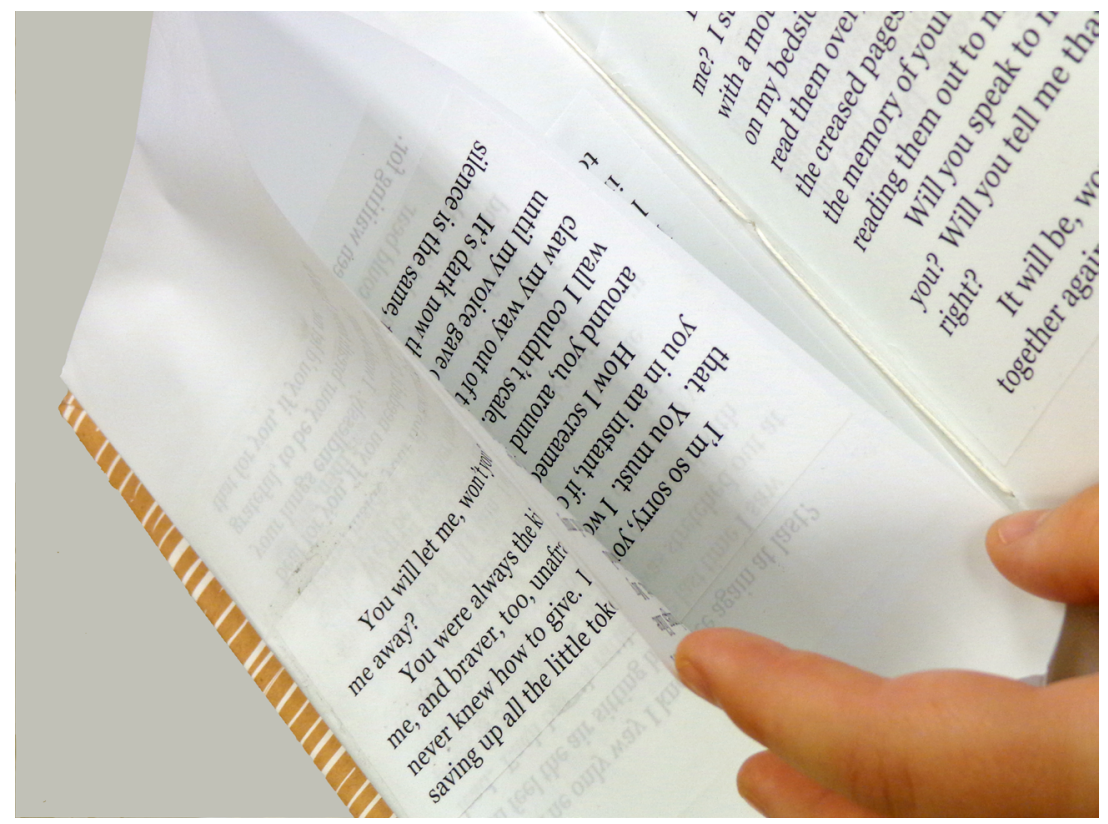

Figure 4. Some of the interior pages on the verso side of the open book are partially accessible, but cannot be turned as they would be in a conventional codex.

is sensible, it's far from the whole story. In short, the construction of the book obscures the text, raising questions about the relationship between form and content (Figure 5).

To explore this relationship, I applied my format to a short story I wrote, "The Hollow," in which a young woman ventures into the woods to find a childhood friend who was lost there years ago. The four accessible pages give away very little of the story: the reader knows that the narrator is going into the woods in search of a long-lost "you," whom in the end she believes she's finally found. But what the reader doesn't know — can't know, without cutting the book open - is the story of how the "you" was lost, which casts the narrator's search and the likelihood of her success in a very different light. From the exterior pages, this story appears to be one of reconciliation after a long and anxiety-ridden absence, while the text as a whole presents instead a grieving friend's descent into self-delusion.

In this way, the format of the book presents two very different versions of the story, which may challenge the reader's efforts to make meaning in the text. The portion of the story the reader has instant access to does not provide the whole picture. A fuller understanding of the text can be made 


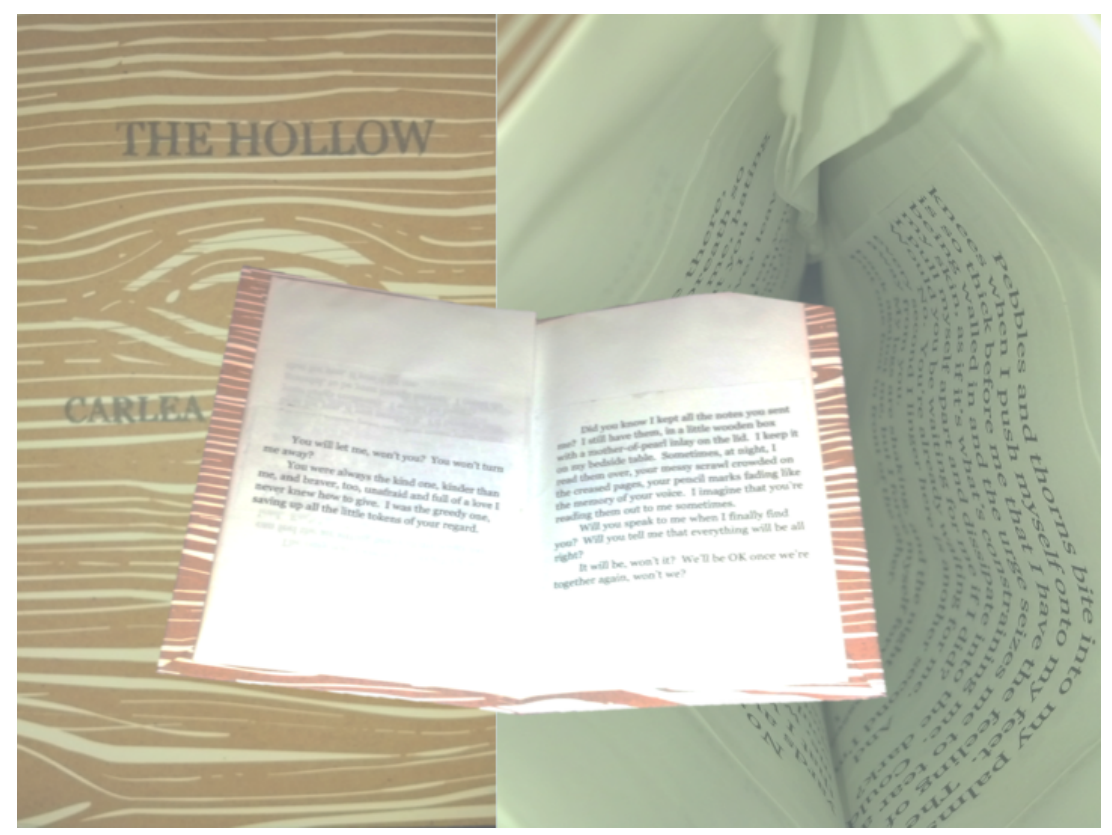

Figure 5. Finished prototype of "The Hollow," showing the front cover (left); a bird's eye shot of partially concealed text (right); and two of the four pages of the story fully accessible to the reader (superimposed image). Twenty-seven pages are concealed due to the way the paper has been folded.

available by cutting the book open, or may not be available at all, if the reader decides not to cut it. But can a work succeed if the majority of its meaning is inaccessible? Is access to those "deeper" levels of significance necessary to construct a text that affects readers emotionally or aesthetically?

In the case of "The Hollow", it's tempting to say that such access is necessary. The abbreviated version is drastically different from the full text, and from my perspective the exterior narrative seems a thinner, less compelling story than the full narrative contained within the enclosed pages. Through the manipulation of form, one text is made into two almost entirely different stories. Though the abbreviated version may seem to depreciate the story, the interplay between these two different versions may ultimately enrich the reader's experience of the work.

In this regard, this format highlights the alterity relation, or the extent to which a given technology becomes conspicuously present to the user. Denying or frustrating access to the text in the conventional way (turning 
consecutive pages to advance the narrative) defamiliarizes the experience of reading, to the point that the reader becomes aware of the book as an object again, rather than as a mere container for text. Meaning is shown to reside not just in the content of the book, but also in how that content is presented on the page.

It may be this focus on form that separates "The Hollow" as a manuscript from "The Hollow" as an artist's book, a medium which Johanna Drucker says "integrates the formal means of its realization and production with its thematic or aesthetic issues" $(2000,376)$. One is a work of fiction. The other is an artifact. Though they both contain the same words, the possibilities of the latter are at once impoverished and enriched because of its relationship to its physical form.

\section{The Pussycat Said to the Owl: Electronic Circuitry in an Altered Book (Clifford Hichar)}

In the development and construction of The Pussycat Said to the Owl, I was reminded of a quote from Thomas Edison: "Genius is one percent inspiration, ninety-nine percent perspiration". The concept for this project was by far the easiest part of the task: to create an artist's book inspired by Tom Phillips' A Humument, Edward Lear's "The Owl and the Pussycat," and Jie Qi's "Computational Sketchbook". Similar to Tom Phillips, I selected a base text, Paul Nixon's Martial and the Modern Epigram, and painted over the pages to reveal my own story. Then I incorporated technology - the Lilypad Arduino - to animate and enhance the book, bringing passages from "The Owl and the Pussycat" to life.

For Phillips and myself, the selection of the text was a matter of chance (MAYNARD 2003, 82). The text was on hand and affordable; I had bought it years earlier under the mistaken impression it was a copy of Martial's Epigrams, rather than a book about them. The haphazard selection of a text is not without ramifications, and it meant having to struggle with a word choice that was not ideal for the story I wished to tell. It was, however, also fortuitous. As I worked on the project, I was forced to confront the affordances of the book - specifically this book. I appreciated the thickness of the page and strong binding, ideal for supporting the Arduino components and use of watercolors. Further, I became acutely aware of details such as the small image of a sailing ship on the title page, which recalled the peagreen boat that is a key image from Lear's "The Owl and the Pussycat".

But why this poem as inspiration for my illustrations and text? I knew that I wanted to work with Lear's "The Owl and the Pussycat" because of 


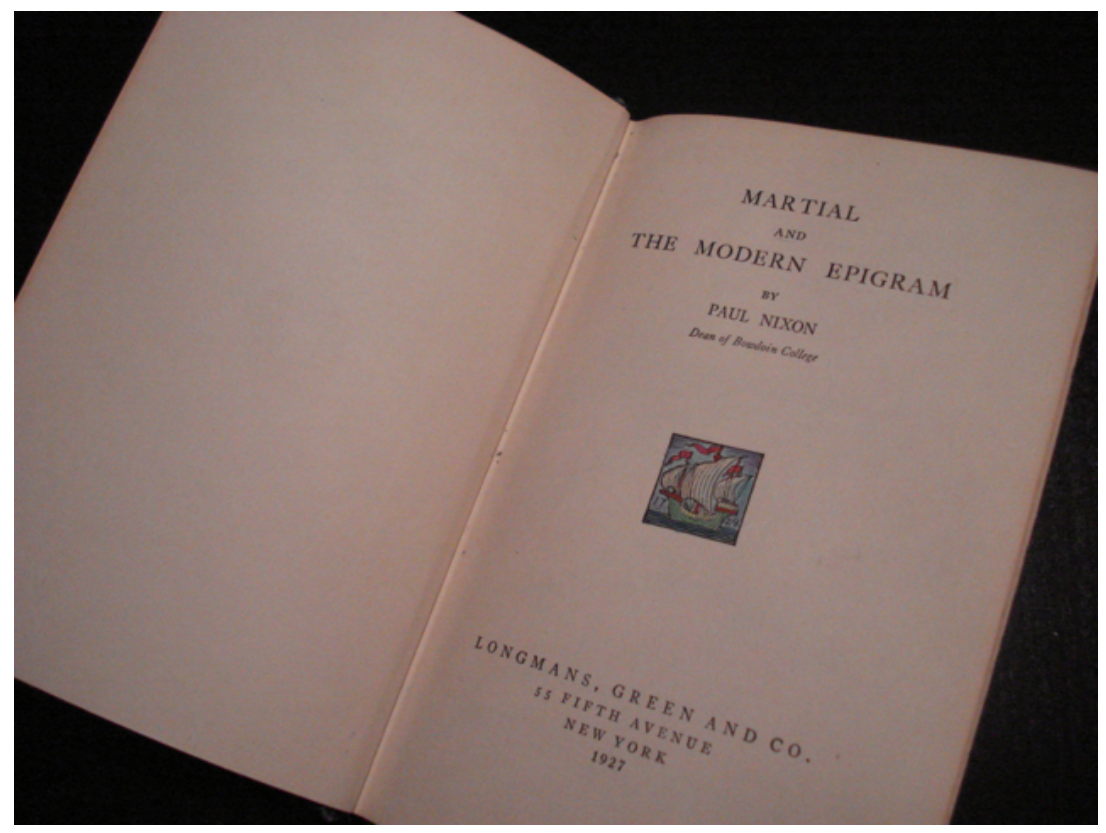

Figure 6. Title Page of the altered book I created showing the small image of the sailing ship, which I painted pea-green in honor of Lear's "The Owl and the Pussycat”.

yet another serendipitous discovery. When I was reading the poem, I came across the unfinished sequel Lear had started, "The Children of the Owl and the Pussycat". In this poem, the Pussycat has died from a fall and left the Owl alone with all their children. The Owl and the Pussycat's children narrate the poem and state:

Our mother died long years ago. She was a lovely cat [... .]

In Sila forest on the East of fair Calabria's shore

She tumbled from a lofty tree - none ever saw her more.

Our owly [sic] father long was ill from sorrow and surprise,

But with the feathers of his tail he wiped his weeping eyes.

(LeAR "Children")

The images seemed so unnatural for a children's tale - too adult, too real, too sad - and it made me think differently about the original poem. What if The Owl and the Pussycat wasn't a children's poem, but was reimagined as a story for adults? What if I were to allow the sequel to color 


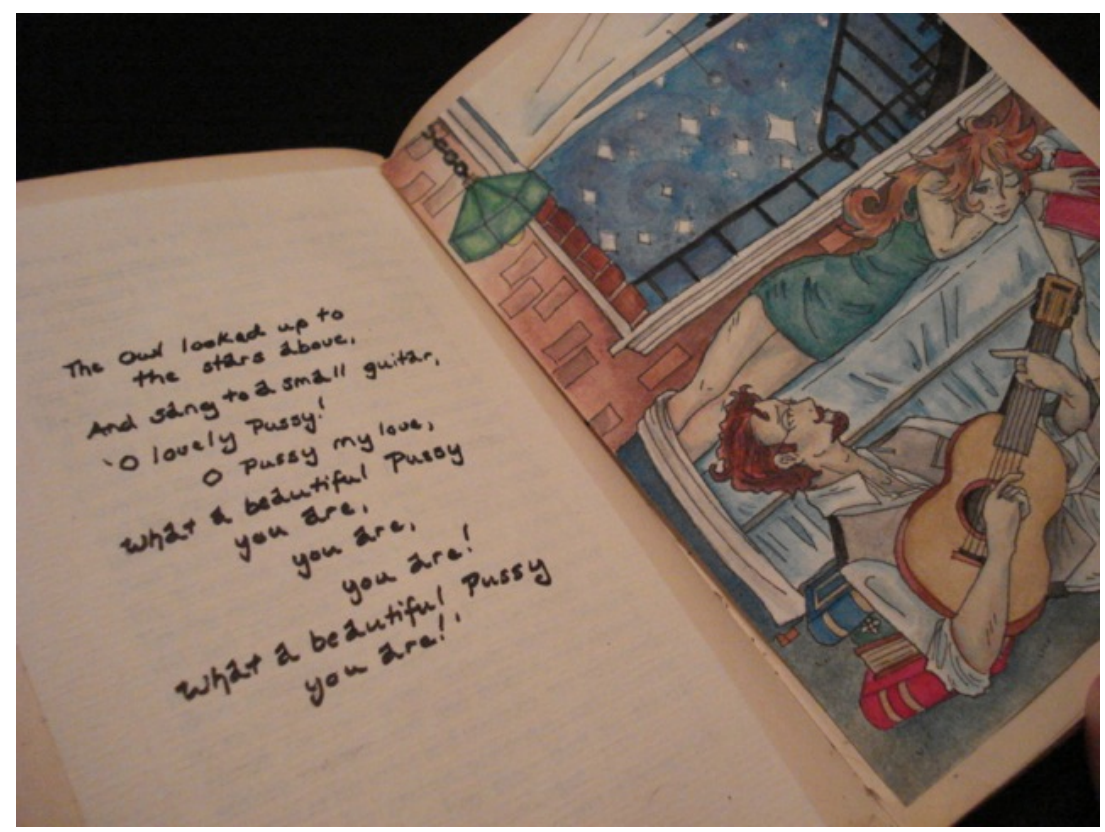

Figure 7. Illustration of the Owl singing to the Pussycat and showing the more mature imagining of the nonsense poem's characters. An Arduino board embedded in subsequent pages controls light-emitting diodes (LEDs) that make the stars visible outside the Pussycat's window twinkle (see also Figure 9).

its predecessor, modernize and update it, and transform the original from a nonsense poem into something grittier and more realistic?

I allowed this concept to influence my illustrations for "The Owl and the Pussycat". In this new light, lines such as "they took some money and plenty of honey wrapped up in a five pound note" suggest that the two didn't have a large income between them, if a five pound note could contain it all-some coins at best. The phrase "plenty of honey", however, signals sweetness and implies they are very much in love. As I carried this interpretation through, I decided that the Owl might be a struggling musician (thus keeping late hours playing in clubs and earning the nickname of a "night-owl"), and he'd work at a rather dingy nightclub and live in a distressed apartment with broken blinds. Further, while I found myself being unconsciously drawn toward more natural images for the romantic passages - a sort of fantasyland among the harsher images of the city - I wanted that world to exist only around the lovers and those that they drew into its orbit such as the Turkey and the Pig. Rather than having the Owl 
and the Pussycat find the Pig in a park, then, I had them encounter him on a deserted street of lamp posts, the "trees" of the city.

This dichotomy between the natural world and the city - between lovers and all the rest-I allowed to continue to play out within the found passages in Martial. ${ }^{7}$ I did not originally intend to do this. As mentioned earlier, while the material affordances of Martial were ideal for my purposes, the language was not and caused some difficulty. On certain pages I struggled to find words that would fit my needs and I was forced to be creative about my placement of the bound pages, covering over the most difficult ones. That alone, though, was not enough to solve the problems I was facing, so I created two voices: the first is masculine and pessimistic, belonging to the world of the city, and speaks in angled "rivers" - a term Phillips uses to describe the connections between words in A Humument. The other I imagined to be a woman's voice who speaks in curves and whose images are optimistic and natural. In this way it allowed me to create passages that could "talk" with each other: one distancing and alienating and the other trying to draw in and play with the other. I felt this approach worked seamlessly with my larger thematic conversations between the past and future of the book, between texts, and between pages. I will concede, though, that doing this was not enough to make the text flow smoothly, but I endeavored to keep it as polished as possible across facing pages of the text, in effect requiring each set of such pages to act as a vignette. In this way, I also allowed comparative space to play a role in my project.

Often the comparative space of a book gets lost in various electronic formats, such as on the Kindle where one is presented with only a single page at a time. While many books don't set about making use of this affordance as a key feature of their design, I wanted to do just that. I designed many of the opposing pages specifically to engage with each other. "The Owl and the Pussycat" passages are arguably the most obvious use of the affordance, but the found passages are the best use of it. For example, on pages 98 and 99 of Martial, I gave each of the voices in the found text a page, allowing the opposing pages to also rhetorically oppose each other (Figure 8). To augment the effect, I drew the backgrounds of these pages to mirror each other. One background features wedding bands and vines - images of life, love, and the binding of things together in a positive way - while

7. I have adopted the phrase "found passages" or "found text" on analogy with the more established "found object" (objet trouvé in French). The term is intended to convey the critical appropriation of pre-existing cultural material - in this case text-into new artistic contexts. 


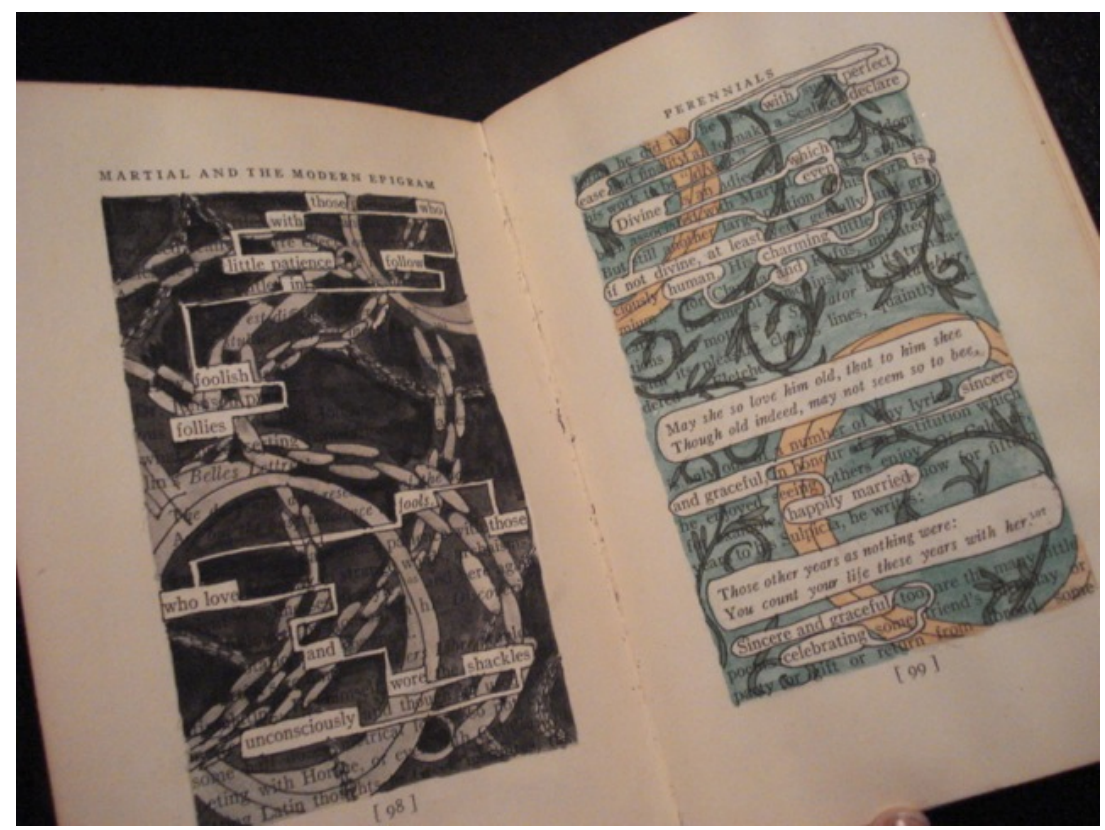

Figure 8. Pages 98 and 99 of the altered Martial showing the use of comparative space and two "voices" in conversation with each other. One voice is visually associated with angles, the other with curves.

on the opposing page the same shapes became those of shackles and chains reflecting the other voice's interpretation of the concept of marriage.

In conclusion, I wanted to set out to challenge and design around specific affordances of the book by playing with the idea of comparative space. Through manipulation of this attribute, facing pages would be allowed to "talk" to each other, and other pages - made thicker by pasting groups of them together-could hide the technology components, thereby highlighting the animations, not the mechanisms responsible for them. Although the determined reader can readily access the microcontrollers, I wanted to make the integration between technology and the book seamless. One must look at the finished product as a whole, understand it as a cyborg, yet also yield to its effects. The reader can pull back the curtain to see how the book is made, but also decline to do so.

Some of the "conversations" that went into the creation of this book will never be seen by a reader at all. In order to learn how to program the Arduino, for example, I was forced to put into conversation different programming guides and software, such as Amici (a visual programming 


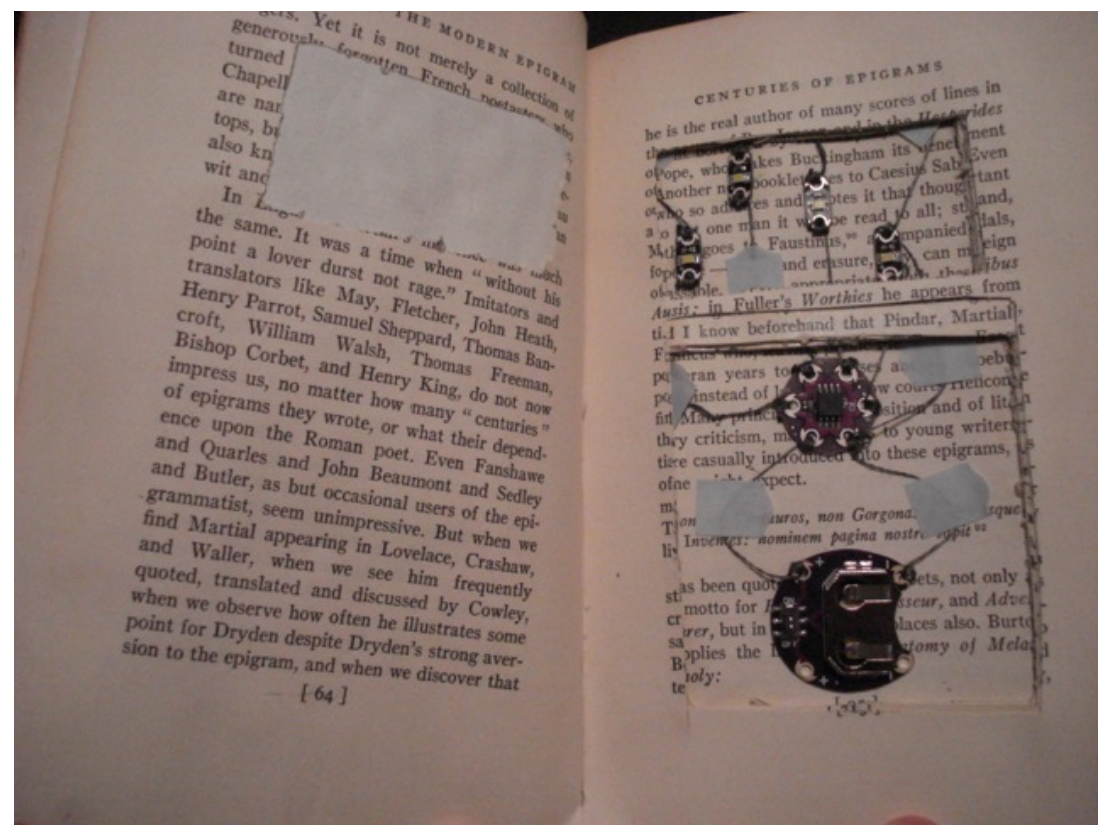

Figure 9. The "guts" or mechanics of the book exposed. On top of the page at right are four tiny LEDs that align with the stars in the illustration on the other side of the adjacent leaf (see Figure 7). The miniature Arduino in the middle, powered by the battery below, is used to control the LEDs (other sections of the book incorporate the original Lilypad Arduino, which is larger in diameter). Conductive threads rather than wires complete the circuit. Near the top of the page at left is a semi-transparent slip of paper, which allows the light from the LEDs to shine through the design on the opposite side.

environment) and the basic Arduino software. By comparing multiple methods for programming different behaviors, I was able to understand the Arduino language and create new code tailored to my unique vision. Even then it took a great deal of experimentation and failure to achieve the desired results. In the end, I was able to make the stage lighting in one illustration change colors, stars in another illustration sparkle, and the moon in a third shine on the lovers' beach dance. In fact, the embedding of the Arduinos and associated LEDs created a three-way conversation of their own among the art, the language, and the technology. The Arduino components - displays, switches, batteries, and circuit boards - only function when connected by the conductive threads. Similarly, the found text of the artist's book only has meaning when the "rivers" - the painted or 
drawn counterparts to the threads - are harmoniously strung together to connect words. The Arduino components illuminate the page, while the "river" components illuminate the text (MAYNARD 2003, 83).

\section{Designing a Multimodal Reading Space for Coleridge's “Kubla Kahn" (Cameron Mozafari)}

My project began in an attempt to reconceive the affordances of the book and to create a more interactive reading experience. By redesigning the codex, I intended to put the emphasis on cognitive meaning making processes, which involve not only the eyes scanning text, but also a full body engagement with the book. The prototype seeks to make apparent Alberto Manguel's assertion that "the pleasure derived from reading largely depends on the bodily comfort of the reader," a comfort I sought to produce - or at least invoke - through speculative design $(1996,151)$. Often, when we want to read most deeply and effectively, we need to get ourselves in a certain mood. We move around or make adjustments in our environment to find something that will trigger that mood for us. Maybe we put on a song, or maybe we read some background information about a text before settling in with the text itself. When reading poetry, for example, we may receive comfort from reciting the lines aloud to get a sense of the meter or the tone of the poem. We may take notes in the margins of the book or circle key words that generate ideas we may wish to return to later. Reading, in other words, is a practice situated in larger medial and physical contexts that can be purposefully altered to create more affective experiences.

In "Bookscapes", Matthew Kirschenbaum (2008) lists five observable structuring affordances of the traditional book. First, the book is both sequential and random access (we can read it linearly or open it to any passage arbitrarily); second, it's a volumetric object that "store[s] information in three-dimensional space"; third, it is finite and bounded; fourth, it has a comparative visual space; and fifth, the book, by virtue of its margins, is writable as well as readable (KIRschenBAum 2008, 1-2). A book, in other words, is a technology designed to promote certain types of use behaviors and discourage others. But books are designed, and designs are arguments. If we don't like the argument, we can always change the design.

With standard e-book devices, many of the affordances of print - for example, comparative visual space-are lost entirely or are simulated through software rather than directly implemented in hardware. By contrast, my interactive project seeks to redesign the codex to both retain Kirschenbaum's five analog affordances and to add additional affordances 


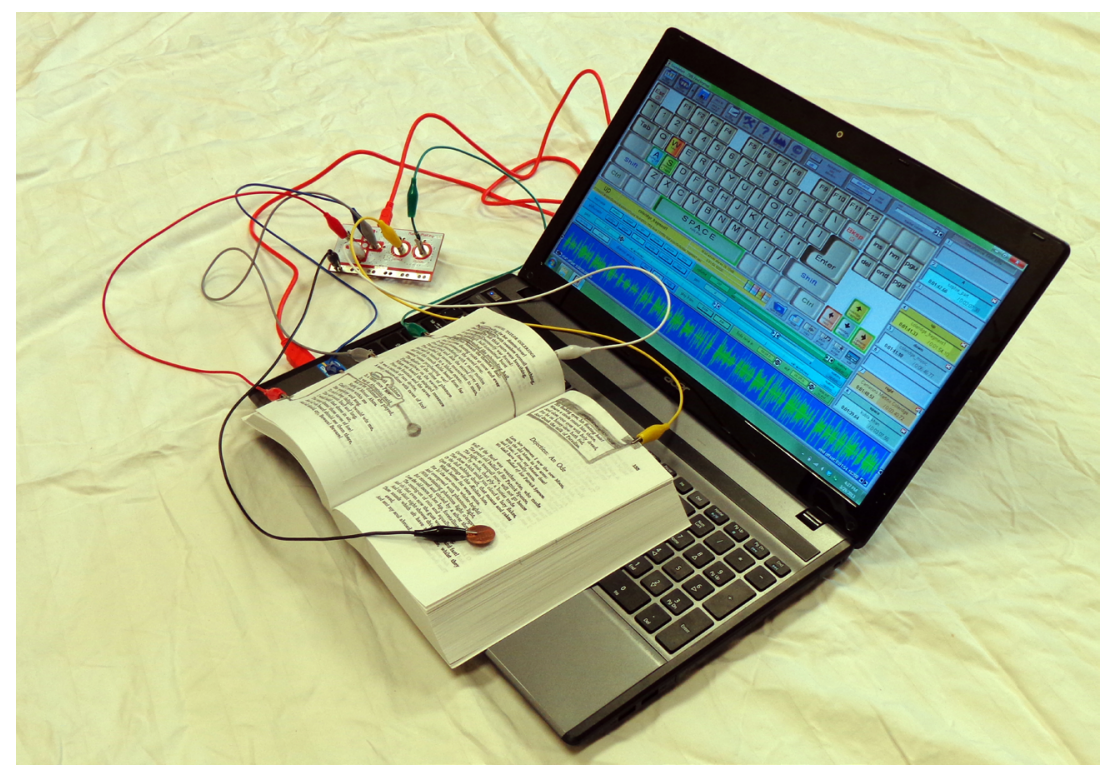

Figure 10. The interactive edition of Coleridge's "Kubla Khan" imposes digital and physical circuitry onto the codex to afford the modality of sound through the modality of touch.

made possible by digital technology, namely touch and sound. These new features support a more multimodal reading experience. Multimodal literacy, as Gunther Kress asserts, is not a theory, but rather "maps a domain of enquiry" where questions about the logics of different modalities can be asked and answered $(2009,54)$. As a functioning prototype, my project expands the modal resources of the book to create an audio-annotated volume. While the idea of connecting print books and sound is in no way novel — indeed, there is a long tradition of speaking picture books sold to children for educational purposes - the ability to quickly engineer one's own working prototype using cheap electronics and creative software is noteworthy.

Combining W. H. Auden and Norman Holmes Pearson's Norton softcover edition of The Portable Romantic Poets with a laptop, a microcontroller, open source software, some clips, some wires, some graphite, and some good old fashioned ingenuity, I constructed a prototype of what an interactive physical book might look and act like. The interface is haptic: when users touch any of the graphite markings on the pages of Samuel Taylor Coleridge's "Kubla Khan," they complete a circuit communicating to the computer that a specific key has been pressed. The computer, which 


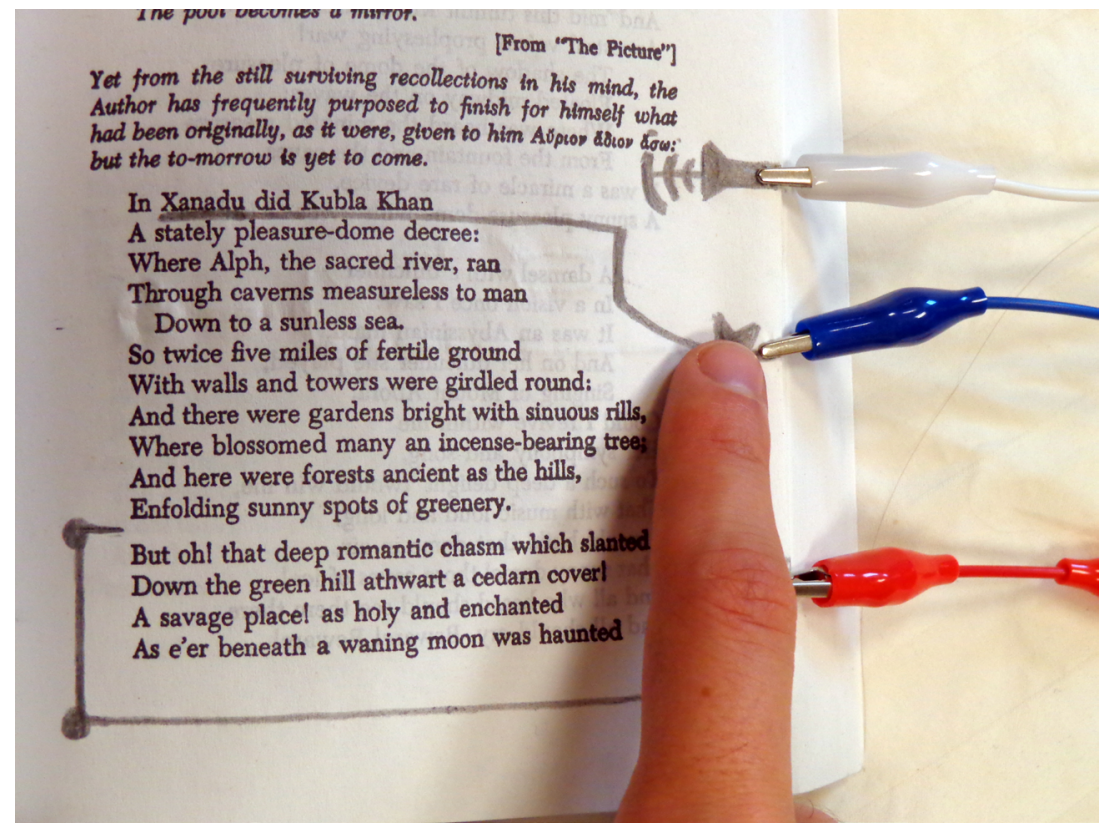

Figure 11. Touching the graphite markings completes a circuit and triggers a prerecorded audio track, managed by software running on the computer.

is running the key-mapping software Soundplant, uses the trigger of the key to start a prerecorded audio clip. Touching the top of the first page of "Kubla Khan," for example, causes calming Chinese hammer and dulcimer music to play and thus sets a complementary reading mood. This music is not only soothing but also adds an immersive contextual element to the reading of the poem, a direct reference to the "damsel with a dulcimer" of the final stanza whose song leads the speaker to contemplate whether he can "revive within [him]/ Her symphony and song" that would allow him to "build that dome in air" (Coleridge 1978, 154). Touching the words "woman," "chasm," "earth," "fountain," or "fragments," on the other hand, initiates critical audio commentary on the sexual innuendo and dull sexism running through the poem. Such critical commentary allows for readers to hear arguments that point to particular passages.

The microcontroller used to connect book to machine is a Makey Makey, which is built on top of the Arduino platform. With it, real-world objects can be made to function as input devices: fruit, wooden blocks, shells, dominoes, beer cans, charms, macaroni, pet rocks, pinwheels, coins, and just about anything else can be used in place of a keyboard to update 


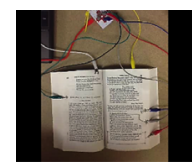

Figure 12. Listening to an argument frees the eyes to explore the text of the passage and to follow the argument's close reading in a multimodal, multisensory real time (click the image for a video clip of the book in operation).

one's status on Facebook, publish to Tumblr, or build a model of the Empire State Building in Minecraft. Created by Jay Silver and Eric Rosenbaum, the Makey Makey's website invites the user to "alligator clip the internet to your world”. The playful marketing slogan echoes William Gibson's 2010 contention that "cyberspace has everted. Turned itself inside out. Colonized the physical". While it is possible to pass data wirelessly between the device and the computer via Bluetooth technology, my own copy of The Portable Romantic Poets is conspicuously tethered to my laptop, making visible the circuitry that connects world and machine.

As Alyson Fielding writes in an online artist statement for her own hybrid, interactive book project, "a digital book shouldn't mean we need to let go of the emotional connection to a physical object, and combining books with technology doesn't have to mean a device with a screen". She continues: "It can be about using the best of technology to further our relationship with the physical book as object". In modifying the design of the book to promote interactivity, we allow for new affordances to reshape our conception of how books are used and what they are used for. We can make explicit various extralinguistic aspects inherent in reading and socially acting upon a given text. My modified pages of "Kubla Khan" allow for more avenues of meaning making than the traditional book affords. Replete with music, sound, recitation, personal commentary, oral performance, and other personalized touches, it models a very different kind of bookscape - and critical edition - than that exemplified by W. H. Auden and Norman Holmes Pearson's Portable Romantic Poets.

\section{The House of Her: An Alternate Narrative Unraveled Through Deformance (Charity Hancock and Kathryn Skutlin)}

Our project was born from a question: "How would a classic text translate using social media as its template?" When we approached the idea of collaborating on an altered text, we decided it would be interesting to invert the tone of a classic work of fiction, ultimately finding ourselves drawn to Gothic literature, as it is cast on one end of the tonal spectrum. Edgar 


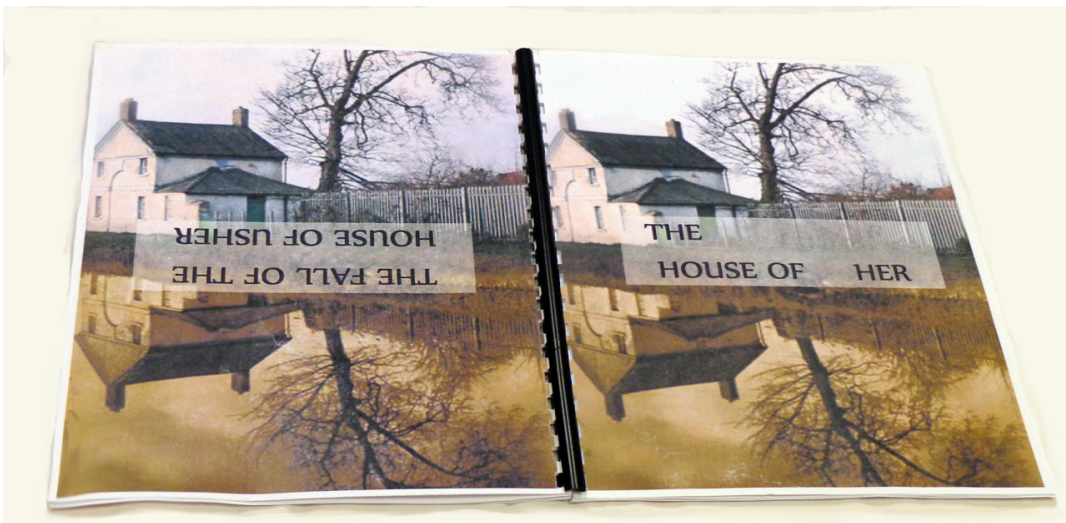

Figure 13. The mirrored covers of The House of Her project, which play off its theme of inversion.

Allan Poe's short story, "The Fall of the House of Usher," proved an excellent candidate due to its brevity, prototypical gothic elements, and its rich potential for diverse interpretations (Figure 13). Since we inverted the text generically, we also decided to work our altered storyline backwards through our source text, juxtaposing the inverted original alongside the altered text. In this way, form mirrors content.

Drawing on Samuels and McGann's concept of deformance, which involves a reader approaching a familiar text, taking it apart, and reassembling it as something new, we were able to offer a new interpretation and open up the liminal spaces within our source text that were previously unexplored. Looking specifically at poetic works, Samuels and McGann, in "Deformance and Interpretation," assert that "the critical and interpretive question is not 'what does the poem mean?' but 'how do we release or expose the poem's possibilities of meaning?"' $(1999,28)$. As Johanna Drucker points out, "Students regularly come to the classroom intent on finding the 'meaning' of a poem within an apparently stable text, as if it were a self-evident and self-identical work" (2009, 67). By deconstructing a text's fundamental framework of meaning, however, one can begin both to deform and perform a work as a text that is alive and mutable, rather than a static work with a fixed arrangement.

Samuels and McGann outline four aspects of deformance: reordered, isolating, altering, and adding (1999, 36-7). For The House of Her we focused on two of these aspects - reordering and altering. Instead of read- 
ing our entire source text backwards word-for-word, we broke down the linearity of "Usher" into paragraphs, the order of which we reversed. By reading the source text backwards, we were able to engage with a "deformative procedure [that] puts the reader in a highly idiosyncratic relation to the work," freeing us to construct an interpretation of our own, unhindered by the story's original trajectory $(1999,36)$. Despite the idiosyncrasies associated with deformance, as Samuels and McGann note, "Reading Backward is a highly regulated method for disordering the senses of a text" (1999, 36). With respect to unraveling our alternate narrative, we faced additional decisions regarding our word-selection process, ultimately constraining ourselves to words composed of letters that originally appear in consecutive order. Instead of a limitation, our self-imposed constraint led us to discover feminine pronouns existing within words such as "Usher" and even "atmosphere," a crucial innovation for our desire to emphasize a character (Madeline Usher) who rarely appears in our source text. We often found ourselves with multiple narrative possibilities within a single paragraph, demonstrating the generative power of our constraint.

When we decided on a blatant destabilization of the narrator's perspective, we risked our text's logic crumbling in on itself, since "The Fall of the House of Usher" is written as a first-person account. To avoid the perceived pitfall of casting every part of Poe's original narrative into doubt, we instituted logical constraints or "truths" that stabilized the framework of The House of Her. Themes from our source text such as the physical and mental decay of the Ushers were kept intact, along with the inciting incident (the narrator going to visit his old friend Roderick Usher). These truths guided the narrative and set a backdrop for our alternate storyline, allowing us to focus mainly on our interest in developing a love story between our narrator, R. T. Arran, and Madeline Usher. Despite our guiding truths, we still were engaged in what McGann and Samuels term a "stochastic process," meaning our narrative was overall an unpredictable one (1999, 36). Taking shape as a Twitter feed, our altered text was constrained by the 140-character limit of tweets as well as contingent upon the availability of words offered to us in the original paragraphs (Figure 14).

For us, each 'invented' tweet of The House of Her expresses the thoughts of R. T. Arran to an invisible audience, chronicling his story for the world to read. We interspersed his tweets with clarifying hashtags, importing material to further mark Arran's progress as a lover caught in the throes of an unrequited love affair. Our decision to add material to the base text was guided by the dual nature of hashtags as external interventions that link the text to preexisting meta-narratives (such as love and devotion) 


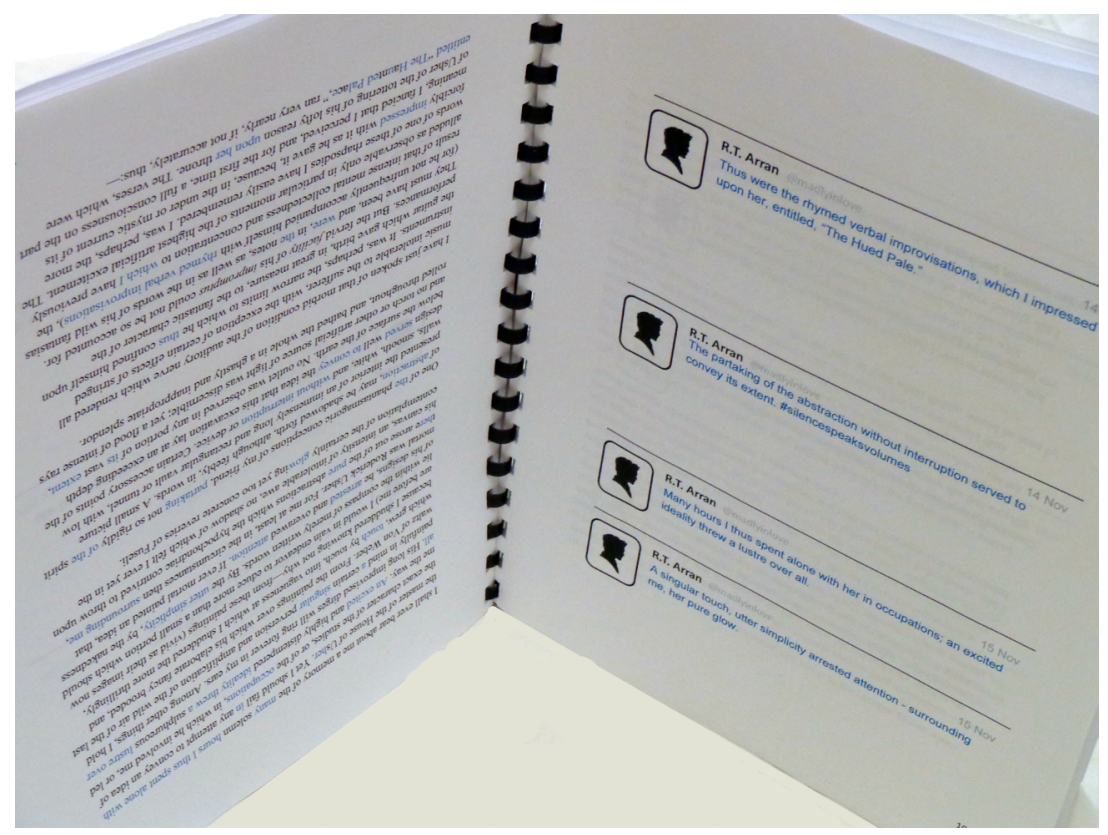

Figure 14. Shot showing the use of comparative visual space for juxtaposing source text (left) and altered $\&$ inverted text (right) in the form of a Twitter timeline. The narrator's name, "R. T. Arran," is "Narrator" spelled backwards. The tweets were derived from the words in blue font visible in the source text at left. We tested each tweet's length by plugging it into Twitter's "compose new tweet" box, which includes a built-in character counter.

as well as humorous commentaries adding to the language of the original tweet. Although readers are unable to respond to Arran's tweets in real time as they would in a live Twitter feed, the blank spaces between his tweets invite our readers to make The House of Her a writable (as well as readable) text.

We consciously chose to present our altered text as multimodal printed literature, a hybrid of sorts that retained Twitter's aesthetic and linguistic features but not its digital medium (GibBons 2012, 1). We wanted to preserve and emphasize the connection between our source text and altered text, as well as capitalize on the series of inversions within The House of Her; by consciously utilizing the print affordance of comparative visual space, juxtaposing the inverted altered text opposite its source, we were able to do so (see Kirschenbaum 2008). Carrying this concept to completion, our finished piece contains a dual narrative - read one way, it's "The Fall of the House of Usher," flip it over, and it's The House of Her. 


\section{Coda: The Design of the Alien Everyday}

In the recently published Digital_Humanities from the MIT Press, the authors - five self-described "practitioner-theorists" — move design thinking to center stage of the humanities (BURDICK ET AL. 2012, vii). Echoing the increasingly pervasive sentiment that one can make arguments with things or, in the words of Ian Bogost, "do philosophy" with artifacts (2012, $85)$, they position design as a core DH competency (12-6). Although more often linked to the studio arts, such practice-led approaches in the humanities are by no means unprecedented: Joseph Viscomi's Blake and the Idea of the Book, for example, brilliantly reverse engineers the nineteenth-century British artist's illuminated books through hands-on experimentation involving the tools, materials, and chemicals Blake would have routinely used in his printmaking shop (1993). Similarly, Anne McCants' course The Distaff Arts teaches MIT students the basics of medieval textile technologies by having them spin and weave (rather than just read about spinning and weaving) (Turkel and Elliott, forthcoming). And recently, William Turkel and Devon Elliott have been exploring the history of stage magic by recreating working models of nineteenth-century physical apparatuses for levitation and vanishing tricks (Turkel AND Elliott, forthcoming). Each of these examples validates the proposition that "when used to pose and frame questions about knowledge, design becomes an intellectual method" (Burdick ET AL. 2012, 13).

The projects described above partake in the venerable tradition of practice-led methods that, as stated in the introduction, have long been associated with History of the Book studies. Where we depart from bibliographical precedent, however, is in our temporal orientation: we have designed these projects less to understand the past than to imagine the future; our point of view is primarily prospective rather than retrospective, although we draw extensively on history. The power of reflective design, as we see it, is that it allows us to carve the book at its joints: to identify, rearrange, mutate, augment, and deform its component parts in order to create a new vision of what a book might be. Understood in these terms, reflective design is the design equivalent of mereology: the study of the relationship of parts to wholes. ${ }^{8}$ In discovering and manipulating parts and material affordances, the book becomes an alien technology, simultaneously "ordinary and weird" (Bogost 2012, 65). The alien, as Ian Bogost writes in Alien Phenomenology, "isn't in the Roswell military morgue, or in the galactic far reaches, or in the undiscovered ecosystems of the deepest sea and most

8. The term is mentioned in Bogost 2012, 22-3. 
remote tundra. It's everywhere" $(2012,133)$. It's in pipe cleaners and earbuds, dandelions and sprockets, plane hangars and toadstools. ${ }^{9}$ And it's in the plainness and strangeness of books. In these projects we see the alien in the co-location of print and digital parts; in the frustration of bolted edges; in the grafting of a social media skin onto the page. They remind us that the affordances of the conventional book aren't permanently baked into the cultural zeitgeist, but can be continuously designed anew. And they remind us - convincingly and bracingly — of "the awesome plenitude of the alien everyday" (Bogost 2012, 134).

University of Maryland

\section{Works Cited}

"Amici Communitybeta". Amici Community. Dimeb and Universitat Bremen, n.d. Web. 30 Mar. 2013. http://dimeb.informatik.uni-bremen.de/eduwear/get-started/.

BanZI, Massimo. 2012. "How Arduino is Open-Sourcing Imagination". TED talk. http://www.ted.com/talks/massimo banzi how arduino is open sourcing imagination.html.

Belanger, Terry and Peter Herdrich. 2007. The Anatomy of a Book: I: Format in the Hand-Press Period. Charlottesville: Book Arts Press.

Bogost, Ian. 2012. Alien Phenomenology. Minneapolis: University of Minnesota Press.

Bonanni, Leonardo. 2009. "Leah Buechley Presents the Computational Sketchbook by Jie Qi at Ars Electronica 2009". http://www.youtube.com/watch?v=lij4rV4h_SA. YouTube, 06 Sept. Web. 24 Oct. 2012.

Bоsсн, Torie. 2012. "Sci-Fi Writer Bruce Sterling Explains the Intriguing New Concept of Design Fiction". Slate 2 March http://www.slate.com/blogs/future tense/2012/03/02/bruce sterling on design fictions .html.

Burdick, Anne, Johanna Drucker, Peter Lunenfeld, Todd Presner, Jeffrey Schnapp. 2012. Digital_Humanities. Cambridge: The MIT Press.

Byrne, Ruth. 2007. The Rational Imagination. Cambridge: The MIT Press.

9. The practice of assembling surprising strings of words is adopted by Bogost, who refers to them as Latour Litanies $(2012,38)$. They're intended to draw attention to the alterity of the mundane everyday. A few examples of Latour Litanies from Alien Phenomenology:

- Mountains, fruit, atmospheric effects, nuclear warheads, sandwiches, automobiles, historical events, relics

- Sea urhins, kudzu, enchiladas, quasars, and tesla coils

- Plumbers, cotton, bonobos, DVD players, and sandstone

- Toilet seats, absinthe louches, seagulls, trampolines 
Coleridge, Samuel Taylor. 1978. "Kubla Khan: or, A Vision in a Dream”. In The Portable Romantic Poets, edited by W H. Auden and Norman Holmes Pearson, 152-5 Penguin Books: New York.

Drucker, Johanna. 2000. "The Artist's Book as Idea and Form”. In A Book of the Book, edited by Jerome Rothenberg and Steven Clay, 376-88. New York: Granary Books.

- 2009. SpecLab: Digital Aesthetics and Projects in Speculative Computing. Chicago: University of Chicago Press.

Fielding, Alyson. "Enchanted books: storytelling through gestures and movement". The Literary Platform. http://www.theliteraryplatform.com/2013/03/enchantedbooks-storytelling-through-gestures-and-movement/.

Gaver, W[illiam]. 1991. "Technology affordances". Proceedings of the CHI. New York: ACM Press. 79-84.

Gibbons, Alison. 2012. Multimodality, Cognition, and Experimental Literature. New York: Routledge.

Gibson, William. “Google’s Earth”. New York Times (New York) August 31, 2010.

http://www.nytimes.com/2010/09/01/opinion/01gibson.html? r=0.

Hayles, N. Katherine. "The Transformation of Narrative and the Materiality of Hypertext". Narrative 9 (2001): 21-39.

IHde, Don. 1990. Technology and the Lifeworld. Bloomington: Indiana University Press. JACKson, Holbrook. 1950 (2001 rpt.). The Anatomy of Bibliomania. Urbana-Champaign: University of Illinois Press.

Johnson, Steven. 2010. Where Good Ideas Come From. New York: Riverhead Books.

Jurgenson, Nathan. 2001 (24 Feb.). "Digital Dualism Versus Augmented Reality". Cyborgology. http://thesocietypages.org/cyborgology/2011/02/24/digital-dualismversus-augmented-reality/.

Kirschen baum, Matthew. 2008. "Bookscapes: Modeling Books in Electronic Space". Human-Computer Interaction Lab 25th Annual Symposium, May 29, 1-2.

Kraus, Kari. 2012. "Introduction”, Rough Cuts: Media and Design in Process (2012), The New Everyday, MediaCommons http://mediacommons.futureofthebook.org/ tne/pieces/introduction.

Kress, Gunther. 2009. "What is Mode?" In The Routledge Handbook of Multimodal Analysis, edited by Carey JewitT and Gunther Kress, 54-66. New York: Routledge.

"Language Reference”. Arduino. Arduino, n.d., accessed 24 Oct. 2012.

LeAr, Edward. 2012. "The Children of the Owl and the Pussy-cat". Edward Lear, The Children of the Owl and the Pussy-cat. Edward Lear Home Page, accessed 06 Dec. 2012. http://www.nonsenselit.org/Lear/pw/cop.html.

- 2012. "The Owl and the Pussycat". Edward Lear, The Owl and the Pussycat. Edward Lear Home Page, accessed Dec. 2012. http://www.nonsenselit.org/Lear/ns/ pussy.html.

Lukens, Jonathan and Carl DiSalvo. 2012. "Speculative Design and Technological Fluency". IJLM 3: 23-40. 
Mangen, Anne. 2008. "Hypertext fiction reading: haptics and immersion". Journal of Research in Reading 31: 404-19.

Manguel, Alberto. 1996. A History of Reading. New York: Penguin.

Maynard, James L. 2003. "I Find/I Found Myself/and/Nothing/More than That': Textuality, Visuality, and the Production of Subjectivity in Tom Phillip's 'A Humument"'. The Journal of the Midwest Modern Language Associate Thinking Post-Identity 36: 82-98.

Medway, Pete. 4 May 2008. "Buildings with Their Guts on the Outside". Blog post. http://petemedway.blogspot.com/2008/05/buildings-with-their-guts-on-outside .html.

Norman, Donald. 2002. The Design of Everyday Things. New York: Basic Books. 2004. Emotional Design: Why We Love (or Hate) Everyday Things. New York: Basic Books.

Parik ka, Jussi. 2012. What Is Media Archaeology? Cambridge, UK; Malden, MA: Polity Press.

Phillips, Tom. “A HUMUMENT”. The Official Site of A HUMUMENT. N.P., 2012. Web. Accessed 24 Oct. 2012.

Pierce, James, and Eric Paulos. 2011. "A Phenomenology of Human-Electricity Relations". In Proceedings of the SIGCHI Conference on Human Factors in Computing Systems: 2405-8.

Piper, Andrew. 2009. Dreaming in Books: The Making of the Bibliographic Imagination in the Romantic Age. Chicago: University of Chicago Press.

Pope, Rob. 1995. Textual Intervention: Critical and Creative Strategies for Literary Studies. London: Routledge.

Samuels, Lisa, and Jerome McGann. 1999. "Deformance and Interpretation". New Literary History 30: 25-56.

Sмith-Welch, Michael. 2013. "Tinkering with Intention: Creative Learning, Computers, and Makerspaces”. Video. 14 March 2013. HCIL Lab. http://www.frequency .com/video/michael-smith-welch-tinkering-with/84273498/-15-1098870.

Sterling, Bruce. 2005. Shaping Things. Cambridge: The MIT Press.

Stewart, Sean, Jordan Weisman, Cathy Brigg. 2008. Cathy's Key. Philadelphia: Running Press.

Turkel, William, and Devon Elliott. Forthcoming. "Making and Playing with Models: Using Rapid Prototyping to Explore the History and Technology of Stage Magic". Past Play. Vancouver: UBC Press.

Viscomi, Joseph. 1993. Blake and the Idea of the Book. Princeton: Princeton University Press.

Wikipedia Contributors. "Greeble”, Wikipedia, The Free Encyclopedia, http:/l en.wikipedia.org/w/index.php?title=Greeble\&oldid=553582186 (accessed May 21, 2013). 